Acta vet. scand. $1961,2,301-310$.

From the Department of Reproductive Physiology and Pathology, Veterinary College of Norway, Oslo.

\title{
A NEW METHOD FOR THE DETECTION AND ESTIMATION OF URINARY OESTROGENS IN THE SOW AND ITS APPLICATION FOR THE EARLY PREGNANCY DIAGNOSIS
}

By

Torleiv Lunaas

With biological methods increased oestrogenic activity in the urine of the sow has been found to occur during the days $22-31$ of pregnancy and during the last weeks prior to parturition (Küst, 1931, and Struck, 1931). For the development of a pregnancy test in the sow several attempts have been made to take advantage of the oestrogenic substances being excreted during the first part of gestation (Cowie, 1948). Both bioassay and simple chemical methods such as the Cuboni test, for the detection of the urinary oestrogens have, however, offered too low accuracy as pregnancy tests in this species to warrant practical application (Grunsell and Robertson, 1953).

The chemical nature of the oestrogens in the urine of the pregnant sow has been unknown until the recent isolation from this source of oestrone (Velle, 1959). Oestrone seems to be the principal urinary oestrogen throughout both periods of excretion (Velle, 1958). A method (Brown, 1955) for the separate determination of this oestrogen in urine collected on one of the days 25-30 after breeding appears to serve as a reliable pregnancy test (Velle, 1960). At the time being the methods available for such determinations are probably not sufficiantly practicable to be extensively used as pregnancy tests. An attempt has therefore been made to devise a more simple and rapid method for the detection and estimation of urinary oestrogens in the sow. In 
this paper a description of the procedure arrived at will be given as well as a discussion of its possible application as a pregnancy test.

Principle.

\section{METHOD}

The water soluble oestrogen conjugates are hydrolysed by adding sulfuric acid to the urine sample in the presence of toluene. The oestrogens thus liberated are extracted with the toluene and the extract washed to eliminate some of the unspecific urinary material. The oestrogens, being weak acids, are subsequently re-extracted from the toluene with alkali and submitted to a modified Kober reaction. The Kober colour substances due to oestrogens are finally extracted (Ittrich, 1958) and the oestrogen concentration evaluated visually or measured colorimetrically.

Reagents and apparatus.

Toluene, technical.

Sulfuric acid, p. a. or chemically pure.

$8.0 \% \mathrm{NaOH}(\mathrm{w} / \mathrm{v})$ in water $(2 \mathrm{~m})$.

$8.4 \% \mathrm{NaHCO}_{3}(\mathrm{w} / \mathrm{v})$ in water $(1 \mathrm{~m})$.

Hydroquinone.

$2 \%$ (w/v) p-nitrophenol in tetrachlorethane or chloroform.

Pyrex glass flasks, $500 \mathrm{ml}$. and $100 \mathrm{ml}$.

Volumetric cylinders, $100 \mathrm{ml}$. and $10 \mathrm{ml}$.

Pipet, $50 \mathrm{ml}$.

Separation funnel, $250 \mathrm{ml}$.

Test tubes or centrifugation tubes.

Procedure.

In a $500 \mathrm{ml}$. pyrex glass flask $100 \mathrm{ml}$. of urine of room temperature $\left(20-25^{\circ} \mathrm{C}\right)$ are mixed with $50 \mathrm{ml}$. of toluene. To the urine and the toluene $50 \mathrm{ml}$. of concentrated sulfuric acid are slowly added from a pipet during constant shaking and swirling of the flask. If excessive foaming occurs the addition of the sulfuric acid should be momentarily interrupted. It is advisable to protect the hand holding the flask with a rubber glove as the temperature of the reaction mixture will rise to about $80^{\circ} \mathrm{C}$. This rise in temperature is sufficient and necessary for a reproducible hydrolysis of the oestrogen conjugates to occur. After the addition of the 
sulfuric acid the flask is briefly shaken a couple of times during the following 2-3 minutes and then left to cool somewhat.

While still rather warm the content of the flask is poured into a separation funnel. The layers will separate and the aqueous phase and most of the solid material under the toluene are tapped off. The toluene is then shaken briefly with $50 \mathrm{ml}$. of water which are discarded with the rest of the solid material. Next the toluene is vigorously shaken for at least half a minute with $15 \mathrm{ml}$. of an $8.0 \% \mathrm{NaOH}$ solution. To the toluene and the $\mathrm{NaOH}$ solution $60 \mathrm{ml}$. of an $8.4 \% \mathrm{NaHCO}_{3}$ solution are added and the shaking repeated, this time less vigorously. Too violent agitation will delay the subsequent separation of the layers. The aqueous phase is again discarded, care being taken to leave no water under the toluene.

Next the toluene is extracted with $12 \mathrm{ml}$. of the $8.0 \% \mathrm{NaOH}$ solution, $10 \mathrm{ml}$. of which are tapped into a $100 \mathrm{ml}$. pyrex flask. Concentrated sulfuric acid, $10 \mathrm{ml}$., are rinsed down the walls of the flask, admixed with the extract and followed by $0.3-0.5 \mathrm{~g}$. (a quarter of a tea spoon) of hydroquinone. The content of the flask is immediately brought to boil over an open flame and kept boiling for about 15 seconds. After 5 minutes $10 \mathrm{ml}$. of water are added and the flask thoroughly cooled under the tap. The Kober colour substances thus formed are finally extracted by shaking with $4 \mathrm{ml}$. of tetrachlorethane (or chloroform) containing $2 \%$ p-nitrophenol.

The time required for the processing of one urine sample is about half an hour.

Visual evaluation of the oestrogen concentration.

Chloroform appears to give more pure extracts of the Kober colour substances than tetrachlorethane and should be preferred when visual evaluation only of the oestrogen concentration is desired.

For visual inspection of the extract it may be poured into a test tube. The Kober colour substances in chloroform (or tetrachlorethane) appear pink in day light and give rise to a characteristic light green fluorescence.

Urine samples containing $20 \mu \mathrm{g}$. of oestrogens (calculated as oestrone) per $100 \mathrm{ml}$. give extracts with a usually distinct pink colour. The lower limit of the amounts detectable by the colour is dependent on the concentration of the urine. Concentrated 
urine samples give extracts with a yellow or light brown colour which can partly cover the specific pink. Urine samples with $50-100 \mu \mathrm{g}$. of oestrogens per $100 \mathrm{ml}$. give extracts with deep pink colour.

Urine samples containing more than $10 \mu \mathrm{g}$. of oestrogens per $100 \mathrm{ml}$. give extracts with strong green fluorescence when examined in the dark by a narrow beam $(0.5 \mathrm{~cm}$. in diameter $)$ from a flashlight. Amounts of oestrogens down to $1 \mu \mathrm{g}$. per $100 \mathrm{ml}$. and less may be detected by the fluorescence. Weak unspecific yellow, occasionally red fluorescence may be seen when the concentration of oestrogens is low.

\section{Colorimetry.}

For colorimetry tetrachlorethane was preferred for the final extraction as the Kober colour substances are somewhat more stable in this solvent than in chloroform. The extracts were centrifuged and the optical densities measured at 500,538 and 576 $\mathbf{m}_{\mu}$. In the present investigation a Beckman DU model spectrophotometer was used. The corrected optical density $\mathrm{E}=\mathbf{2} \mathrm{E}_{538}$ $\left(E_{500}+E_{576}\right)$ was assumed to be linearily related to the amounts of oestrogens which was calculated as oestrone. As standards known amounts of oestrone were added to $50 \mathrm{ml}$. of toluene which was washed and developed as the urinary extracts.

\section{MATERIAL}

Urine samples of 16 sows were collected at various times during the period $17-35$ days after breeding as indicated in Table 1. Included in the material are also some urine samples collected during and after oestrous from normally cycling sows which had not been bred. The specimens from the sows no. 1-11 and no. 14-16 were obtained at micturition and usually stored for $1-3$ days prior to analysis or freezing to $20^{\circ} \mathrm{C}$. The specimens from the sows no. 12, 13, I and II were taken from 24 hours urines and immediately frozen.

\section{RESULTS}

The estimates of urinary oestrogens obtained with the method described when using colorimetry are presented in Table 1. All specimens were also analysed with respect to oestrone using the chromatographic method of Brown (1955) which previously has been shown to be applicable for the urine of the sow (Velle, 1958). 


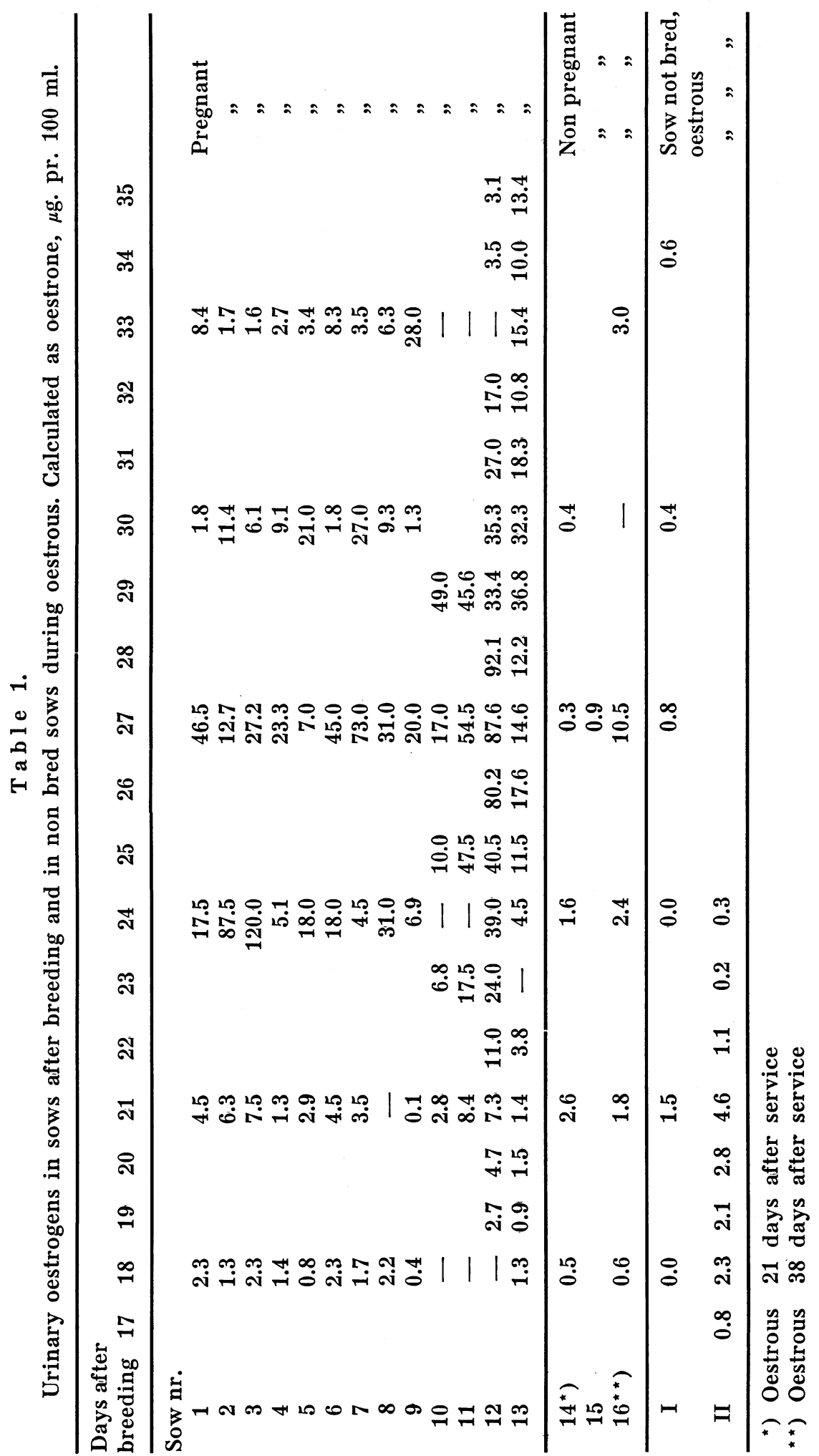


Table 2.

Quantitative estimations of urinary oestrogens with the method described and the method of Brown (1955). Pooled urine sample from pregnant sows.

\begin{tabular}{|c|c|c|c|c|}
\hline \multicolumn{3}{|c|}{$\begin{array}{l}\text { Hydrolysis by adding } 50 \mathrm{ml} \text {. of sulfuric acid to } \\
100 \mathrm{ml} \text {. of urine in the presence of } 50 \mathrm{ml} \text {. of toluene }\end{array}$} & \multirow{2}{*}{\multicolumn{2}{|c|}{$\begin{array}{l}\text { Hydrolysis by refluxing the } \\
\text { urine, } 50 \mathrm{ml} \text {. diluted to } 200 \mathrm{ml} \text {., } \\
\text { with hydrochloric acid, } 30 \mathrm{ml} \text {. } \\
(11 \mathrm{n}) \text { for one hour }\end{array}$}} \\
\hline \multirow{2}{*}{\multicolumn{2}{|c|}{$\begin{array}{l}\text { Aliquote of alkali extract } \\
\text { developed according to } \\
\text { method described }\end{array}$}} & \multirow{2}{*}{$\begin{array}{l}\text { Aliquote of alkali } \\
\text { extract analysed and } \\
\text { developed according } \\
\text { to Brown (1955) }\end{array}$} & & \\
\hline & & & \multicolumn{2}{|c|}{$\begin{array}{l}\text { Analysed and developed } \\
\text { according to Brown (1955) }\end{array}$} \\
\hline $\begin{array}{l}\text { Analysis } \\
\text { no. }\end{array}$ & $\begin{array}{l}\text { Oestrogens }{ }^{\star} \text { ) } \\
\mu \mathrm{g} \cdot \text { per } 100 \mathrm{ml} . \\
\text { of urine }\end{array}$ & $\begin{array}{l}\text { Oestrone }^{\star} \text { ) } \\
\mu \mathrm{g} \cdot \text { per } 100 \mathrm{ml} \\
\quad \text { of urine }\end{array}$ & $\begin{array}{l}\text { Analysis } \\
\text { no. }\end{array}$ & $\begin{array}{l}\text { Oestrone }{ }^{\star \star} \text { ) } \\
\mu \mathrm{g} . \text { per } 100 \mathrm{ml} \text {. } \\
\text { of urine }\end{array}$ \\
\hline 1 & 28.1 & 28.9 & 1 & 30.8 \\
\hline 2 & 27.8 & 32.0 & 2 & 27.7 \\
\hline 3 & 29.3 & 29.0 & 3 & 28.5 \\
\hline 4 & 35.0 & 31.6 & 4 & 27.8 \\
\hline 5 & 32.5 & 31.7 & 5 & 30.0 \\
\hline 6 & 34.4 & 32.6 & 6 & 28.3 \\
\hline
\end{tabular}

*) Referred to known amounts of oestrone $(20 \mu \mathrm{g}$.$) added to 50 \mathrm{ml}$. of toluene prior to washing and extraction with alkali.

${ }^{\star *}$ ) Corrected values. Recovery of oestrone added to urine prior to hydrolyses was $60 \%$.

No major deviations important for the use of the present method as a pregnancy test were revealed.

In Table 2, a comparison between the two methods is presented. It may be seen that the values obtained with the different methods are in reasonable agreement. Occasionally Kober chromogens appeared in the diol fraction of the method of Brown. With the method described oestradiol-17 $\beta$ may be recorded whereas oestriol and oestradiol-17 $\alpha$ are almost not recovered. Neither of these oestrogens seems to be conclusively identified in the urine of the sow.

The recovery of oestrone amounted to slightly more than $40 \%$. Most of the loss was found to be due to incomplete extraction of oestrone from the toluene.

\section{DISCUSSION}

In Table 1. it may be seen that in pregnant sows maximal oestrogen excretion seems to occur between 24 and 27 days after breeding. This is consistant with the previous finding that the most favourable results of bioassay of the oestrogens as a preg- 
nancy test are obtained when the urine sample is collected on one of the days 25-27 after breeding (Grunsell and Robertson, 1953).

The amounts of oestrogens excreted per volume unite of urine are obviously subjected to large individual variations. This may partly be due to variations in the concentration of the urine which in our experience are indeed pronounced in the sow. Another reason for the large variation of the concentration of urinary oestrogens at this stage appears to be that the sows differ with respect to time of maximal excretion after breeding. Analyses performed on 24 hours urine collected from pregnant sows also indicate that the absolute amounts of oestrogens excreted during the time in question vary considerably between sows (unpublished results).

Although the method described seems adequate for the detection of the amounts of oestrogens usually excreted in the pregnant sow, its application as a pregnancy test is complicated by the large variations in the urinary oestrogen concentrations encountered. As mentioned this is partly due to differences in the concentration of the urine. Very dilute urine samples, however, give extracts with almost no visible unspecific colour. In such extracts the specific colour of the oestrogens stands more clearly out but may be weak. For the interpretation of the test a determination of the specific weight of the urine may therefore be helpful.

Analyses of urine from non-pregnant sows out of heat with the method of Brown including spectrofluorimetry indicate that the urine of sows is probably never completely devoid of oestrone. When such urines are analysed with the method described an apparently specific fluorescence may be detected in the tetrachlorethane extract if very strong light sources are applied, but the amounts are usually too small to give significant values of the corrected optical densities.

The amounts found of urinary oestrogens during normal oestrous appears to be representative (unpublished results) and may give a rather distinct fluorescence. A delayed oestrous with weak or missing heat signs after breeding may thus probably cause misinterpretations when the method is used as a pregnancy test.

One of the sows (no. 16) showed no signs of heat until 38 days after breeding but excreted increasing amounts of oestrogens 
from the 18th day. As the oestrogen excretion is probably associated with the attachment of the foeteses a reasonable explanation might be that attachment of the foeteses was initiated and that absorbtion occured.

The pattern of oestrogen excretion during deviating oestrous cycles after breeding as well as that eventually associated with absorbtion of the foeteses are not extensively studied in the sow. The accuracy of the method as a pregnancy test will probably to some, at the present time unknown, degree depend on the frequency of such irregularities of the ovarian functions and the events connected with the implantation.

The time of onset of oestrogen excretion prior to parturition seems to be about the 80th day after breeding (Küst and Struck, 1934) but may vary (Velle, 1958). A pregnancy diagnosis at this late stage would usually be of minor economic importance, but the amounts of oestrogens excreted are easely detectable with the method described (own observations) as they are usually larger than during the first period of excretion.

\section{Acknowledgements.}

This investigation has recieved financial support from the Agricultural Research Council of Norway. Thanks are due to dr. agric. $H$. Skjervold for kind assistance in supplying some of the urine specimens. The skillful technical assistance of Miss Aud Mortensen is appreciated.

\section{REFERENCES}

Brown, J. B.: Biochem. J. 1955, 60, 185.

Cowie, A. T.: Pregnancy Diagnosis Tests. A Review. Commonwealth Agricultural Bureau Joint Publication No. 13. Great Britain, $1948,90$.

Grunsell, C. S. \& Robertson, A.: Vet. Rec. 1953, 65, 366.

Ittrich, G.: Hoppe-Seylers Z. physiol. Chem. 1958, 1, 312.

Küst, D.: Dtsch. tierärztl. Wschr. 1931, 39, 738.

Küst, D. \& Struck, M.: Ibid. 1934, 42, 54.

Struck, M.: Diss. Giessen. 1931.

Velle, W.: Unders $\varnothing$ kelser over naturlig forekommende $\emptyset$ strogener hos drøvtyggere og gris. Thesis Oslo, 1958.

Velle, W.: Acta vet. scand. 1959, 1, 19.

Velle, W.: Vet. Rec. 1960, 72, 116. 


\section{SUMMARY}

A simple chemical method for the detection of urinary oestrogens in the sow is described. The method involves a rapid hydrolysis step, extraction of the free oestrogens, purification of the extract, a modified Kober reaction and extraction of the colour substances formed from the oestrogens. The presence of oestrogens is indicated by a characteristic red colour and a green fluorescence of the final extract. The time required for the processing of one urine sample is about 30 minutes.

The method was shown to be applicable for quantitative estimations of urinary oestrogens when colorimetry is included.

In the pregnant sows investigated the largest amounts of oestrogens were excreted during the last part of the fourth week after breeding. Considerable individual variations were found both with respect to the time of onset of oestrogen excretion and the time of maximal excretion as well as to the amounts excreted.

The application and the accuracy of the method as a pregnancy test is discussed.

\section{ZUSAMMENFASSUNG}

Eine neue Methode zum Nachweis und zur Messung von östrogenen im Harn der Sau und ihre Anwendung zur frühzeitigen Trächtigkeitsdiagnose.

Ein einfaches chemisches Verfahren zum Nachweis von östrogenen im Harn der Sau wird beschrieben. Diese Methode umfasst schnelle Hydrolyse, Extraktion der freien östrogene, Reinigung des Extraktes, eine modifizierte Kober-Reaktion und Extraktion der gefärbten Substanzen, die von den östrogenen gebildet werden. Gegenwart von östrogenen gibt sich durch eine charakteristische rote Farbe und grüne Fluoreszenz im Endextrakt zu erkennen. Die für die Bearbeitung einer Harnprobe erforderliche Zeit beläuft sich auf ungefähr 30 Minuten.

Es zeigte sich, dass sich diese Methode für eine quantitative Bestimmung von Harnöstrogenen anwenden lässt, falls eine Kolorimetrie miteinbezogen wird.

Bei den untersuchten trächtigen Säuen wurden die grössten östrogenmengen während des letzten Teiles der vierten Woche nach dem Decken ausgeschieden. Sowohl im Zeitpunkt der beginnenden Ausscheidung von östrogenen als auch in der maximalen Elimination derselben kamen bedeutende individuelle Variationen vor.

Die Anwendung und Genauigkeit dieses Verfahrens als Trächtigkeitsprobe werden diskutiert. 


\section{SAMMENDRAG}

En ny metode for påvisning og måling av фstrogener $i$ urinen hos purke og dens anvendelse for tidlig drektighetsdiagnose.

Det beskrives en enkel kjemisk metode for påvisning av $\emptyset$ strogener i urinen hos purke. Metoden omfatter et raskt hydrolysetrinn, ekstraksjon av de frie $\emptyset$ strogener, rensning av ekstraktet, en modifisert Koberreaksjon og ekstraksjon av de farvede substanser som dannes av $\emptyset$ strogenene. Nærvær av $\emptyset$ strogener indiseres av karakteristisk r $\varnothing d$ farve og grønn fluorescens i sluttekstraktet. Tiden som kreves for opparbeidelsen av én urinprøve er omtrent 30 minutter.

Det ble vist at metoden er anvendelig for kvantitativ bestemmelse av urinøstrogener når kolorimetri inkluderes.

Hos de drektige purker som ble unders $\varnothing$ kt ble de st $\varnothing r s t e ~ \varnothing s t r o g e n-$ mengder utskilt i siste del av fjerde uke etter bedekning. Betydelige individuelle variasjoner ble funnet både med hensyn på tidspunktet for begynnende utskillelse av фstrogener og maksimal utskillelse, så vel som på de mengder som ble utskilt.

Anvendelsen og nøyaktigheten av metoden som drektighetsprøve diskuteres.

(Received June 17. 1961). 